\title{
The inhibitory effects of plant extracts, vitamins and amino acids on myeloperoxidase activity
}

\author{
Sevim Tunalı' (D), Fatma Yașar Boztaș ${ }^{1}$ (D) Refiye Yanardağ ${ }^{1}$ (D) \\ 'Istanbul University-Cerrahpasa, Faculty of Engineering, Department of Chemistry, Istanbul, Turkey
}

ORCID IDs of the authors: S.T. 0000-0003-3363-1290; F.Y.T. 0000-0002-9538-8030; R.Y. 0000-0003-4185-4363

Cite this article as: Tunali, S., Yasar Boztas, F., \& Yanardag, R. (2020). The inhibitory effects of plant extracts, vitamins and amino acids on myeloperoxidase activity. Istanbul Journal of Pharmacy, 50 (2), 125-130.

\begin{abstract}
Background and Aims: Myeloperoxidase (MPO, EC 1.11.2.2) is a vital antimicrobial enzyme, having a crucial role in host defense. Obstructing the activity of MPO is a possible pharmacological approach for the hindrance and management of a wide array of inflammatory illnesses. Consequently, blocking the activity of MPO is a potential pharmacological strategy for prevention and treatment of a broad range of inflammatory diseases.

Methods: In our study, inhibitory effects of 6 different sulfur containing plant extracts, 16 different vitamins and amino acids were studied for MPO inhibitory activities. The MPO enzyme activity was determined spectrophotometrically according to the method of Wei and Frankel.

Results: Among the aqueous plant extracts, black cabbage extract having $\mathrm{IC}_{50}=0.92 \pm 0.07 \mathrm{mM}$ showed the highest inhibition. Among the vitamins and amino acids studied, the highest MPO enzyme inhibition was exhibited by ascorbic acid with $\mathrm{IC}_{50}=0.01 \pm 0.003$ and cysteine with $\mathrm{IC}_{50}=1.09 \pm 0.73 \mathrm{mM}$.

Conclusion: Based on the outcomes, it was observed that all the examined plant extracts, vitamins and amino acids inhibited MPO enzyme at certain ratios.

Keywords: Myeloperoxidase, enzyme, inhibition, plant extract, vitamins, amino acids
\end{abstract}

\section{INTRODUCTION}

Myeloperoxidase (MPO, EC 1.11.2.2) is a lysosomal hemoprotein found in the azurophilic granules in neutrophils (Unubol et al., 2015). Compared to neutrophils, the human monocytes have fewer MPO-positive granules which are lost into tissue macrophages during differentiation (Malle, Furtmüller, Sattler, \& Obinger, 2007).

In the presence of $\mathrm{H}_{2} \mathrm{O}_{2}, \mathrm{Cl}^{-}$is oxidized to $\mathrm{HOCl}$ by MPO. It also functions as classic peroxidase, thereby producing a series of free radicals and reactive oxygen species (ROS). The inhibitors of MPO have high potentials for the treatment of many inflammatory diseases (Wurtz et al., 2018; Regasini et al., 2008). While many compounds (e.g. azides, anilines, phenols, hydrazides, and hydroxamic acids) are potent inhibitors of MPO activity in vitro, (Wurtz et al., 2018; van der Veen, de Winther, \& Heeringa, 2009; Forbes et al., 2013) they are essentially toxic, consequently inappropriate for use as therapeutic agents (Tian, Ding, Peng, \& Lu, 2017). For these reasons, researchers are constantly in search of new natural medications.

This study was aimed at examining the inhibitory activities of 6 sulfur containing plant extracts, as well as 16 different vitamins and amino acids on MPO enzyme. 


\section{MATERIALS AND METHODS}

\section{Chemicals}

All reagents used in the inhibition of MPO enzyme activity were of analytical grade and commercially available.

\section{Preparation of aqueous plant extracts and other drugs}

Plant materials were washed with water and dried at room temperature. Dried plants $(20 \mathrm{~g})$ were extracted by adding 200 $\mathrm{mL}$ of distilled water and refluxed for 8 hours. The extracts were then filtered and the filtrates were taken to the pre-weighed glass flasks. The glass flasks were placed in a rotary evaporator and the water of the mixtures was evaporated under reduced pressure. Then, extracts were kept in Eppendorf tubes at $-20^{\circ} \mathrm{C}$. Before use, all extracts were dissolved in distilled water at different concentrations. Also, vitamins, amino acids and peptides were prepared by being dissolved in distilled water.

\section{Enzyme inhibitory activity assay}

Rat gastric tissues homogenates were used as the enzyme source. The gastric tissues were homogenized in $0.9 \%$ saline to make up a 10\% (w/v) homogenate. The homogenate was centrifuged at $3000 \mathrm{rpm}$ for 30 minutes at $4^{\circ} \mathrm{C}$ and the supernatant was used for enzyme inhibition experiments.

MPO enzyme inhibitory activity was determined spectrophotometrically according to Wei and Frenkel's method (Wei \& Frenkel, 1991). In a test tube, $1.3 \mathrm{~mL}$ of 4 -aminoantipyrine (25 $\mathrm{mM}$ in $2 \%$ phenol) and $1.5 \mathrm{~mL}$ hydrogen peroxide solutions (1.7 mM) was shaked for $4 \mathrm{~min}$, and $0.1 \mathrm{~mL}$ inhibition solution were added and stirred. The reaction was started by adding $0.2 \mathrm{~mL}$ of homogenate. Then, the change in absorbance was measured at $510 \mathrm{~nm}$ for $5 \mathrm{~min}$. Reference measurements were performed without inhibitors (control value). Quercetin was used as standard.

The potent inhibition of MPO activity was calculated as follows:

MPO Inhibition $(\%)=\frac{(A-B)}{A} \times 100$

$A$ is the enzyme activity without inhibitor. $B$ is the activity in presence of inhibitor. The $\mathrm{IC}_{50}$ was determined as the concentration of plant extract required to inhibit MPO activity by $50 \%$. The results are given as half maximal inhibitory concentrations $\left(\mathrm{IC}_{50}\right)$ values calculated from the regression equations prepared from the concentrations of the samples. Low $I C_{50}$ values indicate higher enzyme inhibitory activity.

\section{RESULTS}

MPO inhibition values of different sulfur containing plant extracts are given in Table 1. High MPO inhibitory action correlates to a low $I_{50}$ value. Decreased inhibition values of plant extracts according to the lowest $I_{50}$ values are as follows: black cabbage $>$ quercetin $>$ white cabbage $>$ purple cabbage > onion > brussels sprouts > cauliflower. As observed from the results, black cabbage $\left(\mathrm{IC}_{50}=0.92 \pm 0.07 \mathrm{mg} / \mathrm{mL}\right)$ and white cabbage $\left(\mathrm{IC}_{50}=8.64 \pm 0.98 \mathrm{mg} / \mathrm{mL}\right)$ displayed the highest MPO inhibitory effects when compared to other species and onion extracts (Table 1).

Table 1. The inhibition of myeloperoxidase activity by various plant extracts.

\begin{tabular}{|c|c|c|c|}
\hline Plant extracts & $\begin{array}{l}\text { Concentration } \\
(\mathrm{mg} / \mathrm{mL})\end{array}$ & $\begin{array}{c}\text { Inhibition } \\
(\%)^{*}\end{array}$ & $\begin{array}{l}\mathrm{IC}_{50} \text { Value } \\
(\mathrm{mg} / \mathrm{mL}) *\end{array}$ \\
\hline Black cabbage & $\begin{array}{c}0.25 \\
0.5 \\
1.0\end{array}$ & $\begin{array}{l}13.2 \pm 4.17 \\
29.2 \pm 5.45 \\
54.2 \pm 4.74\end{array}$ & $0.92 \pm 0.07$ \\
\hline Brussels sprouts & $\begin{array}{c}25 \\
50 \\
100\end{array}$ & $\begin{array}{l}16.3 \pm 3.39 \\
36.3 \pm 5.59 \\
50.2 \pm 0.85\end{array}$ & $95.04 \pm 1.43$ \\
\hline Cauliflower & $\begin{array}{c}25 \\
50 \\
100\end{array}$ & $\begin{array}{c}6.3 \pm 2.05 \\
11.6 \pm 2.83 \\
37.7 \pm 0.64\end{array}$ & $131.13 \pm 3.68$ \\
\hline Onion & $\begin{array}{l}1.25 \\
2.5 \\
5.0\end{array}$ & $\begin{array}{c}5.0 \pm 1.98 \\
6.1 \pm 2.47 \\
12.7 \pm 5.23\end{array}$ & $24.09 \pm 7.71$ \\
\hline Purple cabbage & $\begin{array}{l}1.25 \\
2.5 \\
5.0\end{array}$ & $\begin{array}{c}4.6 \pm 2.90 \\
8.2 \pm 1.13 \\
13.2 \pm 2.19\end{array}$ & $23.96 \pm 9.61$ \\
\hline White cabbage & $\begin{array}{l}0.2 \\
0.5 \\
2.0 \\
5.0\end{array}$ & $\begin{array}{c}6.0 \pm 0.00 \\
14.5 \pm 4.95 \\
23.3 \pm 4.88 \\
31.5 \pm 4.24\end{array}$ & $8.64 \pm 0.98$ \\
\hline Quercetin & $\begin{array}{l}0.2 \\
0.3 \\
0.6 \\
1.0\end{array}$ & $\begin{array}{l}37.36 \pm 2.64 \\
43.68 \pm 2.63 \\
56.32 \pm 8.67 \\
70.69 \pm 3.45\end{array}$ & $1.49 \pm 0.17$ \\
\hline
\end{tabular}


The inhibitory effects of vitamins are shown in Table 2. All the tested compounds exhibited MPO inhibitory activity. Ascorbic acid was found to be the most effective MPO inhibitory agent among the vitamins, its $I C_{50}$ value was $0.01 \pm 0.003 \mathrm{mg} / \mathrm{mL}$ (Table 2). Decreased inhibition values of vitamins to the lowest $I_{50}$ values are as follows: ascorbic acid $>$ DL-a-tocopherol $>$ quercetin $>$ lipoic acid $>$ pyridoxal-5 as-phosphate $>$ DLmethionine methyl sulfonium chloride $>$ nicotinamide $>\beta$ carotene $>$ routine hydrate $>$ riboflavin $>$ anorine hydrochloride.

According to Table 3, the amino acid with the lowest $I C_{50}$ value was L-cysteine. Cysteine was found to have the most effective MPO inhibitory activity among the amino acids, with an $I_{50}$ value of $1.09 \pm 0.73 \mathrm{mg} / \mathrm{mL}$ (Table 3). The highest inhibition values of the peptides and amino acids are as follows: L-cysteine $>$ reduced glutathione $>$ quercetin $>$ L-lysine $>$ L-glutamic acid $>$ L-methionine $>$ L-alanine.

\section{DISCUSSION}

MPO is a heme enzyme which uses $\mathrm{H}_{2} \mathrm{O}_{2}$ and $\mathrm{Cl}^{-}$to catalyse the production of the reactive and cytotoxic oxidant hypochlorous acid (HOCl) (Daugherty, Dunn, Rateri, \& Heinecke, 1994). The initial product of the MPO $\mathrm{H}_{2} \mathrm{O}_{2}-\mathrm{Cl}^{-}$system is the potent antimicrobial oxidant hypochlorous acid/hypochlorite $(\mathrm{HOCl} /$ $\left.\mathrm{OCl}^{-}\right)$. However, under pathological conditions, persistent activation of the MPO- $\mathrm{H}_{2} \mathrm{O}_{2}$ system of activated phagocytes may adversely affect tissues. $\mathrm{HOCl}$ is able to initiate modification reactions targeting lipids, DNA and (lipo)proteins, including halogenation, nitration and oxidative cross-linking (Malle et al. 2007). Also, MPO - mediated damage is involved in the pathogenesis of several inflammatory conditions, atherosclerosis, demyelinating diseases of the central nervous system and some tumors (Unubol et al., 2015).

As a result of systematic studies, plants have been used in modern medicine, phytotherapy and pharmacy according to

Table 2. The inhibition of myeloperoxidase by vitamins.

\begin{tabular}{|c|c|c|c|}
\hline Plant extracts & $\begin{array}{l}\text { Concentration } \\
(\mathrm{mg} / \mathrm{mL})\end{array}$ & $\begin{array}{l}\text { Inhibition } \\
(\%)^{*}\end{array}$ & $\begin{array}{l}I_{50} \text { Value } \\
(\mathrm{mg} / \mathrm{mL}) *\end{array}$ \\
\hline Anorine hydrochlorid & $\begin{array}{c}2.5 \\
5.0 \\
10.0\end{array}$ & $\begin{array}{r}5.8 \pm 2.19 \\
9.8 \pm 2.90 \\
14.4 \pm 3.25\end{array}$ & $40.86 \pm 5.05$ \\
\hline Ascorbic acid & $\begin{array}{c}2.5 \\
5.0 \\
10.0\end{array}$ & $\begin{array}{l}68.6 \pm 8.06 \\
83.8 \pm 3.82 \\
91.5 \pm 1.77\end{array}$ & $0.01 \pm 0.003$ \\
\hline$\beta$-carotene & $\begin{array}{l}1.0 \\
2.5 \\
5.0\end{array}$ & $\begin{array}{r}7.9 \pm 0.99 \\
12.2 \pm 1.91 \\
22.2 \pm 2.47\end{array}$ & $12.85 \pm 1.12$ \\
\hline$( \pm)$-a-Lipoic acid & $\begin{array}{l}0.3 \\
0.5 \\
1.0\end{array}$ & $\begin{array}{c}2.3 \pm 0.49 \\
9.9 \pm 2.62 \\
10.5 \pm 0.42\end{array}$ & $5.05 \pm 0.22$ \\
\hline DL-methionine methylsulfonium chloride & $\begin{array}{l}0.5 \\
1.0 \\
2.5\end{array}$ & $\begin{array}{c}7.0 \pm 1.13 \\
8.7 \pm 2.90 \\
18.3 \pm 5.44\end{array}$ & $8.31 \pm 2.18$ \\
\hline Nicotinamide & $\begin{array}{l}1.0 \\
2.5 \\
5.0\end{array}$ & $\begin{array}{r}6.5 \pm 2.05 \\
12.9 \pm 2.05 \\
24.0 \pm 5.66\end{array}$ & $11.54 \pm 3.07$ \\
\hline Pyridoxal-5'-phosphate & $\begin{array}{l}0.5 \\
1.0 \\
2.5\end{array}$ & $\begin{array}{r}4.2 \pm 2.89 \\
4.7 \pm 0.89 \\
17.8 \pm 1.51\end{array}$ & $7.20 \pm 1.17$ \\
\hline Riboflavin & $\begin{array}{l}1.0 \\
2.5 \\
5.0\end{array}$ & $\begin{array}{c}4.8 \pm 1.56 \\
8.7 \pm 1.13 \\
30.8 \pm 0.50\end{array}$ & $16.14 \pm 7.17$ \\
\hline Routine hydrate & $\begin{array}{c}2.5 \\
5.0 \\
10.0\end{array}$ & $\begin{array}{l}31.3 \pm 1.77 \\
38.9 \pm 0.78 \\
43.3 \pm 2.97\end{array}$ & $13.00 \pm 2.67$ \\
\hline DL-a-tocopherol acetate & $\begin{array}{c}2.5 \\
5.0 \\
10.0\end{array}$ & $\begin{array}{c}5.3 \pm 3.75 \\
8.6 \pm 4.03 \\
19.5 \pm 6.93\end{array}$ & $0.03 \pm 0.01$ \\
\hline Quercetin & $\begin{array}{l}0.5 \\
1.0 \\
2.0 \\
3.0\end{array}$ & $\begin{array}{l}37.36 \pm 2.64 \\
43.68 \pm 2.63 \\
56.32 \pm 8.67 \\
70.69 \pm 3.45\end{array}$ & $1.49 \pm 0.17$ \\
\hline
\end{tabular}


Table 3. The inhibition of myeloperoxidase by amino acids and peptides.

\begin{tabular}{|c|c|c|c|}
\hline Plant extracts & $\begin{array}{c}\text { Concentration } \\
(\mathrm{mg} / \mathrm{mL})\end{array}$ & $\begin{array}{c}\text { Inhibition } \\
(\%)^{*}\end{array}$ & $\begin{array}{l}I_{50} \text { Value } \\
(\mathrm{mg} / \mathrm{mL})^{*}\end{array}$ \\
\hline L-Alanine & $\begin{array}{l}10.0 \\
25.0 \\
50.0\end{array}$ & $\begin{array}{c}3.0 \pm 1.77 \\
5.6 \pm 1.20 \\
12.5 \pm 2.26\end{array}$ & $215.99 \pm 55.54$ \\
\hline L-Cysteine & $\begin{array}{c}5.0 \\
10.0 \\
20.0\end{array}$ & $\begin{array}{l}59.4 \pm 3.25 \\
85.3 \pm 1.20 \\
98.8 \pm 0.57\end{array}$ & $1.09 \pm 0.73$ \\
\hline L-Glutamic acid & $\begin{array}{l}10.0 \\
25.0 \\
50.0\end{array}$ & $\begin{array}{l}14.3 \pm 5.16 \\
29.1 \pm 1.20 \\
43.7 \pm 0.71\end{array}$ & $57.73 \pm 2.71$ \\
\hline L-Lysine & $\begin{array}{c}2.5 \\
5.0 \\
10.0\end{array}$ & $\begin{array}{c}3.0 \pm 0.85 \\
6.2 \pm 0.00 \\
10.4 \pm 4.03\end{array}$ & $54.91 \pm 19.41$ \\
\hline L-Methionine & $\begin{array}{c}5.0 \\
10.0 \\
20.0\end{array}$ & $\begin{array}{c}2.3 \pm 1.41 \\
5.6 \pm 2.33 \\
11.6 \pm 1.84\end{array}$ & $83.80 \pm 17.19$ \\
\hline Reduced glutathione (GSH) & $\begin{array}{c}5.0 \\
10.0 \\
20.0\end{array}$ & $\begin{array}{l}33.4 \pm 0.49 \\
71.8 \pm 2.05 \\
92.3 \pm 0.42\end{array}$ & $7.43 \pm 0.32$ \\
\hline Quercetin & $\begin{array}{l}0.5 \\
1.0 \\
2.0 \\
3.0\end{array}$ & $\begin{array}{l}37.36 \pm 2.64 \\
43.68 \pm 2.63 \\
56.32 \pm 8.67 \\
70.69 \pm 3.45\end{array}$ & $1.49 \pm 0.17$ \\
\hline
\end{tabular}

the effects of secondary metabolites and their composition. The use of synthetic drugs in general provides an effective and rapid treatment. But in some cases, high dose intake causes various side effects on the organism and systems. Thus, the use of herbal medicines or their active components represents alternatives for the treatment of numerous inflammatory disease (Castro, Ocampo \& Franco, 2014). Some food derived polyphenols flavonoids and phenolic antioxidants have inhibitory effects on MPO (Kato, Nagao, Terao, \& Osawa, 2003). Many studies demonstrate that extracts of different parts of various plant species such as Peganum harmala (Bensalem et al., 2014), Ginkgo biloba (Tian et al., 2015) Careya arborea (Begum, Sharma, Pillai, Aeri, \& Sheliya, 2015), Tragopogon graminifolius (Farzaei et al., 2015), Costus igneus (Krishnan, Mathew \& Vijayalakshmi 2014), Urera aurantiaca (Riedel, Marrassini, Anesini, \& Gorzalczany, 2015) Arctium lappa (Wu et al., 2014) Punica granatum (Bachoual, Talmoudi, Boussetta, Braut, \& El-Benna, 2011), Onosma armeniacum (Cadirci, Suleyman, \& Aksoy, 2007), Vaccinium corymbosum (Torri et al., 2007), Mangifera indica (Garrido, González, Lemus, Delporte, \& Delgado, 2006) and Iberis amara L. (Schempp, Hippeli, Weiser, Kelber, \& Elstner, 2004) have shown significant effects on MPO enzyme inhibition.

Studies on cabbage species have shown that they contain flavonoids, ascorbic acid, DL-a-tocopherol acetate and DL-methionine methyl sulfonium chloride (vitamin U) (Podsędek, 2007; Sokmen, Tunali, \& Yanardag, 2012). Podsedek (2007) reported that the vitamin C level of Brassica vegetables considerably differ among and within their subspecies. As observed from the results of this study, black and white cabbage exhibited the highest inhibitory activities at the concentration of $1 \mathrm{mg} /$ $\mathrm{mL}(54.2 \pm 4.74 \%)$ and $5 \mathrm{mg} / \mathrm{mL}(31.5 \pm 4.24 \%)$, respectively on MPO enzyme activity. These inhibition values are thought to be caused by significant amounts of ascorbic acid, carotenoids, DL-a-tocopherol acetate and phenolic compounds in black cabbage and white cabbage. Many studies reported that flavonoids and polyphenols in natural extracts inhibit MPO at micromolar concentrations (Regasini et al., 2008; Kostálová, Misíková, \& Gáborová, 2001), and most of them are competitive substrates for MPO, through the production of $\mathrm{HOCl}$ and other hypohalides (Sokmen, Tunali, \& Yanardag, 2012).

Ascorbic acid is a hydrophilic compound and acts directly by scavenging lipid hydroperoxide, superoxide and hydroxyl radicals, or indirectly by playing an important role in recycling tocopherol, a process that results in the conversion of ascorbic acid into a semiascorbyl radical (Bursać-Mitrović et al., 2016). In this study, ascorbic acid was found as having the most effective MPO inhibitory activity among the vitamins, its $I_{50}$ value was $0.01 \pm 0.003 \mathrm{mg} / \mathrm{mL}$. Black cabbage contains considerably high levels of ascorbic acid.

L-Cysteine is an amino acid containing the sulfhydryl group that has a critical role in preventing oxidative stress in cells. In our study, cysteine was found to have the most effective MPO inhibitory activity among the amino acids, with an $I C_{50}$ value of $1.09 \pm 0.73 \mathrm{mg} / \mathrm{mL}$. Sagone et al. (1989) demonstrated that a sulfur centered compound - dimethylthiourea inhibited the 
MPO enzyme by blocking the formation of $\mathrm{HOCl}$, and can also react with $\mathrm{H}_{2} \mathrm{O}_{2}$ in certain experimental systems (Sagone Jr., Husney, Wewers, Herzyk, \& Davis, 1989). On the other hand, sulfides were found to exhibit protective effects against several pathological diseases. Pálinkás et al., (2015) and Garai et al., (2017) suggested that this effect is possibly due to the obstruction of MPO-mediated oxidant production and/or synthesis of sulfane sulfur (via MPO catalysed sulfide oxidation by neutrofilproduced $\mathrm{H}_{2} \mathrm{O}_{2}$ ) (Garai et al., 2017).

\section{CONCLUSION}

The results of this study indicate that sulfur containing plant extracts, vitamins and amino acids are effective inhibitors of MPO activity. It may be suggested that these compounds and the plant extracts serve as alternative and complementary treatments in regulating immune responses in inflammatory regions when appropriate concentrations are added to a controlled diet.

Peer-review: Externally peer-reviewed.

Author Contributions: Conception/Design of Study- S.T., R.Y.; Data Acquisition- S.T., F.Y.B., R.Y.; Data Analysis/Interpretation- G S.T., F.Y.B., R.Y.; Drafting Manuscript- S.T., R.Y.; Critical Revision of Manuscript- S.T., R.Y.; Final Approval and Accountability- S.T., F.Y.B., R.Y.; Technical or Material Support- S.T., R.Y.; Supervision- S.T., R.Y.

Conflict of Interest: The authors have no conflict of interest to declare.

Financial Disclosure: The Scientific Research Projects Coordination Unit of Istanbul University (Project number: 42160) supported this work.

\section{REFERENCES}

- $\quad$ Bachoual, R., Talmoudi, W., Boussetta, T., Braut, F., \& El-Benna, J. (2011). An aqueous pomegranate peel extract inhibits neutrophil myeloperoxidase in vitro and attenuates lung inflammation in mice. Food and Chemical Toxicology, 49, 1224-1228.

- Begum, R., Sharma, M., Pillai, K. K., Aeri, V., \& Sheliya, M. A. (2015). Inhibitory effect of Careya arborea on inflammatory biomarkers in carrageenan-induced inflammation. Pharmaceutical Biology, 53, 437-445.

- Bensalem, S., Soubhye, J., Aldib, I., Bournine, L., Nguyen, A. T., Vanhaeverbeek, M. ... Duez, P. (2014). Inhibition of myeloperoxidase activity by the alkaloids of Peganum harmala L. (Zygophyllaceae). Journal of Ethnopharmacology, 154, 361-369.

- Bursać-Mitrović, M., Milovanović, D.R., Mitić, R., Jovanović, D., Sovrlić, M., Vasiljević, P. ... Manojlović, N. (2016). Effects of Lascorbic acid and alpha-tocopherol on biochemical parameters of swimming-induced oxidative stress in serum of guinea pigs. The African Journal of Traditional, Complementary and Alternative Medicines, 13, 29-33.

- Cadirci E., Suleyman, H., \& Aksoy, H. (2007). Effects of Onosma armeniacum root extract on ethanol-induced oxidative stress in stomach tissue of rats. Chemico-Biological Interactions, 170, 40-48.

- $\quad$ Castro, J. P., Ocampo, Y. C., \& Franco, L. A. (2014). In vivo and in vitro anti-inflammatory activity of Cryptostegia grandiflora Roxb. ex R. Br. leaves. Biological Research, 47, 32.

- Daugherty, A., Dunn, J. L., Rateri, D. L., \& Heinecke, J. W. (1994). Myeloperoxidase, a catalyst for lipoprotein oxidation, is expressed in human atherosclerotic lesions. The Journal of Clinical Investigation, 94, 437-444.
Farzaei, M. H., Ghasemi-Niri, S. F., Abdolghafari, A. H., Baeeri, M., Khanavi, M., Navaei-Nigjeh, M. ... Rahimi, R. (2015). Biochemical and histopathological evidence on the beneficial effects of Tragopogon graminifolius in TNBS-induced colitis. Pharmaceutical Biology, 53, 429-436.

- $\quad$ Forbes, L. V., Sjögren, T., Auchère, F., Jenkins, D. W., Thong, B., Laughton, D. ... Kettle, A. J. (2013). Potent reversible inhibition of myeloperoxidase by aromatic hydroxamates. The Journal of Biological Chemistry, 288, 36636-36647.

- Garai, D., Ríos-González, B. B., Furtmüller, P, G., Fukuto, J. M., Xian, M., López-Garriga, J. ... Nagy P. (2017). Mechanisms of myeloperoxidase catalyzed oxidation of $\mathrm{H} 2 \mathrm{~S}$ by $\mathrm{H} 2 \mathrm{O} 2$ or $\mathrm{O} 2$ to produce potent protein Cys-polysulfide-inducing species. Free Radical Biology and Medicine, 113, 551-563.

- $\quad$ Garrido, G., González, D., Lemus, Y., Delporte, C., \& Delgado, R. (2006). Protective effects of a standard extract of Mangifera indica L. (VIMANG ${ }^{\circledR}$ ) against mouse ear edemas and its inhibition of eicosanoid production in $\mathbf{J 7 7 4}$ murine macrophages. Phytomedicine, 13, 412-418.

- Kato, Y., Nagao, A., Terao, J., \& Osawa, T. (2003). Inhibition of myeloperoxidase-catalyzed tyrosylation by phenolic antioxidants in vitro. Bioscience, Biotechnology, and Biochemistry, 67, 1136-1139.

- Kostálová, D., Misíková, E., \& Gáborová, G. (2001). Polyphenol compounds from Hamamelis virginiana L. Ceska a Slovenska Farmacie, 50, 51-53.

- $\quad$ Krishnan, K., Mathew, L. E., Vijayalakshmi, N. R., \& Helen, A. (2014). Anti-inflammatory potential of $\beta$-amyrin, a triterpenoid isolated from Costus igneus. Inflammopharmacology, 22, 373-285.

- Malle, E., Furtmüller, P. G., Sattler, W., \& Obinger, C. (2007). Myeloperoxidase: a target for new drug development? British Journal of Pharmacology, 152, 838-854.

- Pálinkás, Z., Furtmüller, P. G., Nagy, A., Jakopitsch, C., Pirker, K. F., Magierowski, M. ... Nagy, P. (2015). Interactions of hydrogen sulfide with myeloperoxidase. British Journal of Pharmacology, 172, 1516-1532.

Podsędek, A. (2007). Natural antioxidants and antioxidant capacity of Brassica vegetables: A review. LWT-Food Science and Technology, 40, 1-11.

Regasini, L. O., Vellosa, J. C., Silva, D. H., Furlan, M., de Oliveira O. M., Khalil, N. M. ... Bolzani, V. S. (2008). Flavonols from Pterogyne nitens and their evaluation as myeloperoxidase inhibitors. Phytochemistry, 69, 1739-1744

- $\quad$ Riedel, R., Marrassini, C., Anesini, C., \& Gorzalczany, S. (2015). Antiinflammatory and antinociceptive activity of Urera aurantiaca. Phytotherapy Research, 29, 59-66.

- $\quad$ Sagone Jr., A. L., Husney, R. M., Wewers, M. D., Herzyk, D. J., \& Davis, W. B. (1989). Effect of dimethylthiourea on the neutrophil myeloperoxidase pathway. Journal of Applied Physiology, 67, 1056-1062.

- Schempp, H., Hippeli, S., Weiser, D., Kelber, O., \& Elstner, E. F. (2004). Comparison of the inhibition of myeloperoxidase-catalyzed hypochlorite formation in vitro and in whole blood by different plant extracts contained in a phytopharmacon treating functional dyspepsia. Arzneimittelforschung, 54, 389-395.

- Sokmen, B. B., Tunali, S., \& Yanardag, R. (2012). Effects of vitamin $\mathrm{U}$ (S-methyl methionine sulphonium chloride) on valproic acid induced liver injury in rats. Food and Chemical Toxicology, 50, 3562-3566.

- Tian, R., Ding, Y., Peng, Y.Y., \& Lu, N. (2017). Inhibition of myeloperoxidase-and neutrophil-mediated hypochlorous acid formation in vitro and endothelial cell injury by (-)-epigallocatechin gallate. Journal of Agricultural and Food Chemistry, 65, 3198-3203. 
- Tian, X. X., Wang, B. L., Cao, Y. Z., Zhong, Y. X., Tu, Y. Y., Xiao, J. B. ... Zhai, L. N. (2015). Comparison of protective effects of safflor injection and extract of Ginkgo biloba on lung ischemia/reperfusion injury in rabbits. Chinese Journal of Integrative Medicine, 21, 229-233.

- Torri, E., Lemos, M., Caliari, V., Kassuya, C.A., Bastos, J. K., \& Andrade, S. F. (2007). Anti-inflammatory and antinociceptive properties of blueberry extract (Vaccinium corymbosum). Journal of Pharmacy and Pharmacology, 59, 591-596.

- Unubol, M., Yavasoglu, I., Kacar, F., Guney, E., Omurlu, I. K., Ture, M. ... Bolaman, Z. (2015). Relationship between glycemic control and histochemical myeloperoxidase activity in neutrophils in patients with type 2 diabetes. Diabetology \& Metabolic Syndrome, 7,119 . van der Veen, B. S., de Winther, M. P., \& Heeringa, P. (2009). Myeloperoxidase: molecular mechanisms of action and their relevance to human health and disease. Antioxidants and Redox Signaling, 11, 2899-2937.

- Wei, H., \& Frenkel, K. (1991). In vivo formation of oxidized DNA bases in tumor promoter-treated mouse skin. Cancer Research, 11, 4443-4449.

- Wu, X., Yang, Y., Dou, Y., Ye, J., Bian, D., Wei, Z. ... Dai, Y. (2014). Arctigenin but not arctiin acts as the major effective constituent of Arctium lappa L. fruit for attenuating colonic inflammatory response induced by dextran sulfate sodium in mice. International Immunopharmacology, 23, 505-515.

Wurtz, N. R., Viet, A., Shaw, S. A., Dilger, A., Valente, M. N., Khan, J. A. ... Kick E. K. (2018). Potent triazolopyridine myeloperoxidase inhibitors. ACS Medicinal Chemistry Letters, 9, 1175-1180. 